\title{
PERSEPSI GURU TERHADAP IMPLEMENTASI KEBIJAKAN ZONASI SEKOLAH DALAM PENERIMAAN PESERTA DIDIK BARU (PPDB) DI KEC. RAPPOCINI MAKASAR
}

\author{
Aliem Bahri ${ }^{1}$, Muhammad Nawir ${ }^{2}$, Abdan Syakur ${ }^{3}$, Junaidi ${ }^{4}$ \\ Prodi PGSD, Universitas Muhammadiyah Makasar \\ 1aliem bahri@yahoo.co.id
}

\begin{abstract}
Abstrak
Undang-Undang Nomor 20 Tahun 2003 tentang Sisdiknas menyebutkan bahwa setiap warga negara mempunyai hak yang sama untuk memperoleh pendidikan yang bermutu. Namun fenomena yang terjadi saat ini terdapat kesenjangan yang cukup kasat mata karena maraknya sekolah negeri berlabel unggul yang digagas oleh pemerintah di hampir setiap daerah yang tentu membuka jurang kesenjangan yang begitu lebar dengan sekolah lain yang notabene berstatus tidak unggul. Sekolah unggulan terkesan hanya bisa dinikmati anak-anak dengan kemampuan akademik serta finansial tertentu. Orang tua murid pun berlomba untuk menyekolahkan anaknya di sekolah unggulan. Sehingga dampaknya ada sekolah yang banyak muridnya dan ada sekolah yang kekurangan. Tentu saja ketidakmerataan ini akan menimbulkan akses yang tidak baik pada dunia pendidikan nasional. Menyikapi hal tersebut, pemerintah melalui Kementerian Pendidikan dan Kebudayaan menetapkan Permendikbud Nomor 17 Tahun 2017 tentang Penerimaan Peserta Didik Baru pada Taman Kanak Kanak, Sekolah Dasar, Sekolah Menengah Pertama, Sekolah Menengah Atas, Sekolah Menengah Kejuruan atau bentuk Lain Yang Sederajat. Dalam Permendikbud tersebut ditetapkan pemberlakuan sistem zonasi dalam penerimaan peserta didik baru. Dalam sistem zonasi diatur bahwa sekolah yang diselenggarakan oleh pemerintah daerah wajib menerima calon peserta didik yang berdomisili pada radius zona terdekat dari sekolah, paling sedikit sebesar 90 persen dari total jumlah keseluruhan peserta didik yang diterima. Penelitian ini bertujuan untuk mengungkap persepsi guru terhadap pelaksanaan kebijakan zonasi sekolah dalam PPDB di Kecamatan Rappocini Kota Makassar. Jenis penelitian ini menggunakan penelitian kualitatif dengan pendekatan studi kasus. Teknik pengumpulan data dilakukan melalui wawancara dengan guru dan dinas terkait juga didukung oleh studi literatur yang berhubungan dengan kebijakan zonasi sekolah. Berdasarkan temuan peneliti, diterapkannya sistem zonasi dalam penerimaan peserta didik baru menimbulkan pro kontra di kalangan guru. Ada yang setuju diterapkannya sistem zonasi agar predikat sekolah favorit hilang dan agar supaya meratanya pendidikan. Di sisi lain ada yang berpandangan bahwa sistem zonasi belum siap untuk diterapkan karena sumber daya manusia (Guru) belum memadai dan sarana prasarana di sekolah juga belum siap
\end{abstract}

Kata Kunci: Persepsi, Kebijakan Zonasi Sekolah.

\section{PENDAHULUAN}

UU Nomor 20 Tahun 2003 tentang Sisdiknas dalam Pasal 5 ayat 1 menyebutkan bahwa setiap warga negara mempunyai hak yang sama untuk memperoleh pendidikan yang 
bermutu. Namun fenomena yang terjadi saat ini terdapat kesenjangan yang cukup kasat mata karena maraknya sekolah-sekolah negeri berlabel unggul yang digagas pemerintah di hampir setiap kabupaten/kota.

Marthunis (2017) menyebutkan bahwa sekolah unggulan disinyalir menjadi prioritas utama Dinas Pendidikan dan Kebudayaan dalam pemenuhan standar nasional pendidikan dan sudah menjadi rahasia umum bahwa sekolah unggul diperlakukan layaknya anak emas oleh dinas terkait.

Input sekolah yang berasal dari kalangan "eksklusif" membuat banyak privilege yang diberikan bagi sekolah unggulan, seperti pemenuhan sarana dan prasarana yang lengkap untuk menunjang proses pembelajaran, tenaga pengajar pilihan yang kompeten dan profesional, serta menjadi prioritas utama dalam pemberian akses untuk mengikuti berbagai perlombaan yang sifatnya regional, nasional, maupun internasional.

Hal ini tentu membuka jurang kesenjangan yang begitu lebar dengan sekolah-sekolah lain yang berstatus tidak unggul. Sekolah unggulan terkesan hanya bisa dinikmati anakanak dengan kemampuan akademik serta finansial tertentu. Orangtua murid pun berlomba untuk menyekolahkan anaknya di sekolah unggulan. Sehingga dampaknya ada sekolah yang banyak muridnya dan ada sekolah yang kekurangan siswa. Tentu saja ketidakmerataan ini akan menimbulkan pandangan yang tidak baik pada dunia pendidikan nasional. Menyikapi hal tersebut, pemerintah melalui Kementerian Pendidikan dan Kebudayaan menetapkan Permendikbud Nomor 17 Tahun 2017 tentang Penerimaan Peserta Didik Baru (PPDB) pada Taman Kanak-Kanak, Sekolah Dasar, Sekolah Menengah Pertama, Sekolah Menengah Atas, Sekolah Menengah Kejuruan atau bentuk Lain Yang Sederajat. Permendikbud tersebut mengatur tentang mekanisme pelaksanaan PPDB agar berjalan secara objektif, akuntabel, transparan dan tanpa diskriminasi.

PPDB sendiri dilaksanakan melalui mekanisme dalam jejaring (daring/online) maupun dengan mekanisme luar jejaring (luring/offline). Persyaratan calon peserta didik diantaranya adalah menyangkut perihal kecukupan usia dan persyaratan administratif (khusus untuk calon peserta didik tingkat SMP dan SMA/SMK) terkecuali untuk peserta didik yang berkebutuhan khusus yang akan bersekolah di sekolah pendidikan inklusif.

Selain persyaratan tersebut, Permendikbud 17 Tahun 2017 menetapkan syarat tambahan dalam proses seleksi calon peserta didik yaitu 
ketentuan zonasi. Dalam sistem zonasi diatur bahwa sekolah yang diselenggarakan oleh pemerintah daerah wajib menerima calon peserta didik yang berdomisili pada radius zona terdekat dari sekolah, paling sedikit sebesar 90 persen dari total jumlah keseluruhan peserta didik yang diterima.

Dengan adanya sistem zonasi ini diharapkan penerimaan peserta didik baru dapat berjalan tanpa diskriminasi dan mampu memberikan kesempatan yang sama bagi setiap peserta didik untuk mengenyam pendidikan formal, terlepas dari kemampuan kognitif ataupun ekonomi yang rendah. Sistem zonasi merupakan sistem penerimaan peserta didik baru yang diberlakukan dengan penentuan radius zona oleh pemerintah daerah masing-masing dan Sekolah wajib menerima calon peserta didik yang berdomisili pada radius zona terdekat dengan persentase tertentu dari total jumlah peserta didik yang akan diterima. Sistem zonasi yang merupakan rekomendasi dari Ombudsman Republik Indonesia pada tahun 2016 kepada Kemendikbud, Kemendagri, dan Kemenag ini kemudian dilaksanakan oleh Menteri Pendidikan dan Kebudayaan Muhadjir Effendy dengan tujuan untuk menghilangkan predikat sekolah favorit dan tidak favorit, agar tercipta pemerataan kualitas pendidikan di seluruh sekolah di Indonesia.

\section{METODE PENELITIAN}

Pendekatan penelitian ini merupakan penelitian kualitatif. Metode kualitatif merupakan prosedur yang menghasilkan data deskriptif berupa kata-kata yang tertulis atau lisan dari orang-orang dan perilaku yang dapat diamati. Menurut Lexy J.Moleong (2007) dalam penelitian kualitatif, peneliti atau dengan bantuan orang lain merupakan alat pengumpul data. Hal ini dikarenakan, orang-orang bisa sebagai instrumen yang sangat luwes dapat menilai keadaan dan mengambil keputusan. Selain itu, hanya manusia sajalah yang dapat berhubungan dengan responden atau objek lainnya dan hanya manusia yang mampu memahami kaitannya dengan kenyataan di lapangan.

Tekhnik pengumpulan data dari penelitian tersebut adalah observasi, wawancara, dan dokumentasi. Penelitian tersebut akan mengungkap atau menggambarkan persepsi guru terhadap implementasi sistem zonasi PPDB, berdasarkan Permendikbud Nomor 17 Tahun 2017 tentang Penerimaan Peserta Didik Baru pada Taman Kanak Kanak, Sekolah Dasar, Sekolah Menengah Pertama, Sekolah Menengah Atas, Sekolah Menengah Kejuruan atau bentuk Lain yang sederajat. Adapun yang menjadi subjek penelitian ini adalah Guru SMP dan 
SMA di Kecamatan Rappocini Kota Makassar.

\section{HASIL DAN PEMBAHASAN}

Salah satu upaya nyata pemerintah dalam rangka pemerataan pendidikan ini pemerintah mengeluarkan aturan baru dalam penerimaan peserta didik melalui Peraturan menteri pendidikan dan kebudayaan no 17 tahun 2017 tentang Penerimaan Peserta Didik Baru (PPDB), yang di Dalam permendikbud tersebut, diatur mengenai sistem zonasi yang harus diterapkan sekolah dalam menerima calon peserta didik baru.

\section{Berdasarkan Permendikbud}

Nomor 17 Tahun 2017, dengan menerapkan sistem zonasi, sekolah yang diselenggarakan oleh pemerintah daerah wajib menerima calon peserta didik yang berdomisili pada radius zona terdekat dari sekolah paling sedikit sebesar 90 persen dari total jumlah peserta didik yang diterima. Domisili calon peserta didik tersebut berdasarkan alamat pada kartu keluarga yang diterbitkan paling lambat enam bulan sebelum pelaksanaan PPDB.

Sistem zonasi ini merupakan sistem yang mengharuskan sekolah untuk menerima semua calon peserta didik yang mendaftar sesuai zonasinya tanpa terkecuali. Dengan demikian, diharapkan akan mengurangi eksklusifitas, rivalitas serta diskriminasi di sekolah sekolah negeri yang merupakan barang publik (public goods).
Tidak ada lagi sekolah favorit dan tidak favorit. Dengan sistem zonasi sekolah maka yang dipakai bukan lagi lokasi sekolah atas dasar pemerintahan tetapi seberapa jauh tempat tinggal siswa dengan sekolah. Diharapkan biaya akomodasi siswa untuk menuju sekolah dapat lebih kecil. Sistem zonasi sekolah juga dapat membuat peserta didik yang pintar bisa menyebar di sekolah sekolah. Dengan demikian siswa pintar bisa membantu siswa yang kesulitan dalam belajar.

Tentang inplementasi sistem zonasi dalam penerimaan peserta didik, berbagai polemik muncul dari kalangan guru. Pro kontra pun hadir sebagai penguat alasan dalam inplementasi aturan tersebut. Berikut adalah hasil wawancara peneliti dengan beberapa guru terkait persepsinya tentang sistem zonasi. "Tujuan utama dari pendidikan sebenarnya adalah mencerdaskan orang yang belum cerdas. Selama ini, saya lihat banyak sekolah favorit itu menjadi sekolah favorit bukan karena sistem pendidikan di sekolah tersebut bagus, akan tetapi karena memang pada dasarnya input siswa mereka dari awal memang sudah bagus. Siswa di sekolah favorit itu pintar-pintar dan jebolannya bagus bukan karena sekolahnya, tapi karena memang siswanya sudah pintar sejak awal"

Sistem zonasi ini seharusnya bisa digunakan untuk menunjukkan bahwa sekolah favorit itu memang sebenarnya memiliki kualitas yang lebih baik 
daripada sekolah yang mungkin dianggap non favorit. Kalau ternyata kualitas lulusan sekolah favorit tiba-tiba jeblok dengan sistem zonasi, berarti asumsi saya benar, bahwasannya sekolah favorit itu jadi bagus bukan karena memang sekolahnya bagus, akan tetapi karena memang mereka dari awal hanya mau menerima siswa pintar saja. Bahwa sebenarnya sistem yang ada di sekolah favorit itu sama saja dengan sekolah non favorit.

Jika tujuan Mendikbud adalah ingin meratakan keluaran murid dari setiap sekolah, maka perbaikilah pemerataan guru-guru berkompeten di daerah-daerah dan setelah itu, sistem zonasi baru bisa diterapkan. Hal ini karena siswa cerdas sendiri bukan faktor terbesar penentu sekolah bisa mempunyai predikat "favorit", melainkan guru-guru yang menguasai bidang keilmuan dan penyampaian materi lah yang menjadikan suatu sekolah mempunyai predikat "favorit". Sungguh terlalu!

Sistem zonasi tidak cocok diterapkan di seluruh wilayah Indonesia karena jumlah sekolah saja belum merata di setiap daerah, apalagi daerah terpencil. Di daerah saya misalnya, di kecamatan kami ada beberapa sekolah yang menumpuk di satu lokasi. Sedangkan di kecamatan lain, bahkan jumlah sekolah sangat sedikit sehingga dikhawatirkan tidak akan berimbang. Di sekolah yang berada di satu lokasi, tentu akan memilih sekolah yang favorit. Nah, sekolah favorit terpaksa menerima mereka tanpa mengukur kemampuan yang dimiliki oleh anak-anak. Jika ingin menerapkan sistem zonasi, pemerintah harus membenahi dulu sekolah-sekolah yang masih sedikit jumlahnya di kecamatan tertentu. Memberikan bantuan jangan ke sekolah yang sudah maju saja, sekolah yang kurang maju seharusnya lebih diperhatikan lagi. Jangan seenaknya saja membuat aturan tapi tidak dibarengi dengan perbaikan-perbaikan infrastruktur sekolah.

$$
\text { Asri ulfah, dkk (2016:4) }
$$
menyatakan "penerimaan peserta didik baru merupakan salah satu kegiatan yang pertama kali dilakukan dalam sebuah lembaga pendidikan, yang tentunya penerimaan peserta didik baru tersebut melalui penyeleksian yang telah ditentukan oleh pihak lembaga pendidikan kepada calon peserta didik baru." Penerimaan peserta didik dalam sebuah lembaga pendidikan merupakan hal yang sangat penting, karena dengan adanya penerimaan peserta didik yang dikelola secara profesional akan memberi keuntungan sekolah dalam bidang pendaftaran yang nantinya akan menjadi peserta didik pada lembaga pendidikan tersebut. Dengan adanya peserta didik yang masuk menjadi peserta didik baru secara otomatis operasional sekolah akan memberikan keuntungan, dan proses belajar 
mengajar yang akan dilaksanakan akan berjalan dengan lancar, karena pembelajaran merupakan satu kesatuan antara peserta didik dan tenaga pendidik.

Peserta didik baru diatur dengan Peraturan Menteri Pendidikan dan Kebudayaan No. 17 Tahun 2017 tentang Penerimaan Peserta Didik Baru pada Taman Kanak-Kanak, Sekolah Dasar, Sekolah Menengah Pertama, Sekolah Menengah Atas, Sekolah Menengah Kejuruan, atau Bentuk Lain yang Sederajat. Penerimaan Peserta Didik Baru dilaksanakan melalui mekanisme dalam jejaring (daring/online) maupun luar jejaring (luring/offline).

Dalam pasal 15 permendikbud no 17 tahun 2017 dijelaskan bahwa dengan menerapkan sistem zonasi, sekolah yang diselenggarakan oleh pemerintah daerah wajib menerima calon peserta didik yang berdomisili pada radius zona terdekat dari sekolah paling sedikit sebesar 90 persen dari total jumlah peserta didik yang diterima. Domisili calon peserta didik tersebut berdasarkan alamat pada kartu keluarga yang diterbitkan paling lambat enam bulan sebelum pelaksanaan PPDB. Radius zona terdekat ditetapkan oleh pemerintah daerah sesuai dengan kondisi di daerah tersebut. Kemudian sebesar 10 persen dari total jumlah peserta didik dibagi menjadi dua kriteria, yaitu lima persen untuk jalur prestasi, dan lima persen untuk peserta didik yang mengalami perpindahan domisili. Namun, sistem zonasi tersebut tidak berlaku bagi sekolah menengah kejuruan (SMK).

Dalam Permendikbud no 17 tahun 2017 pasal 12 dan 13 disebutkan bahwa seleksi PPDB pada kelas VII SMP dan kelas $X \quad$ SMA/SMK mempertimbangkan kriteria dengan urutan prioritas sesuai dengan daya tampung berdasarkan ketentuan rombongan belajar. Urutan prioritas itu adalah: 1. Jarak tempat tinggal ke sekolah sesuai dengan ketentuan zonasi; 2. Usia; 3. Nilai hasil ujian sekolah (untuk lulusan SD) dan Surat Hasil Ujian Nasional atau SHUN (bagi lulusan SMP); dan 4. Prestasi di bidang akademik dan non-akademik yang diakui sekolah sesuai dengan kewenangan daerah masing-masing.

Polemik tentang implementasi sistem zonasi dalam penerimaan peserta didik baru mengundang banyak reaksi. Bukan hanya dari kalangan guru, orangtua, dan siswa. Ketua umum ikatan guru Indonesia melalui media online ia menyampaikan bahwa: "program zonasi sebagai kebijakan pemerintah yang dikeluarkan Mendikbud Muhadjir Effendy adalah bentuk pemerataan pendidikan. Hal itu dikemukakan Ramli kepada media, menanggapi progres pendidikan di Indonesia memperingati Hari Pendidikan Nasional di Makasar, Sulawesi Selatan, Selasa. Menurut dia, program zonasi ini bukan hanya memaksa siswa 
bersekolah di samping rumahnya tetapi juga bercita-cita menjadikan semua sekolah sama baiknya".

Kebijakan zonasi yang diterapkan pemerintah selama tiga tahun terakhir belum sepenuhnya berjalan lancar dan sesuai harapan masyarakat. Kebijakan zonasi yang telah diimplementasikan belum sepenuhnya didukung kebijakan mutu pendidikan lain, termasuk kelengkapan infrastruktur sekolah. Minimnya sosialisasi pemerintah daerah ke sekolah-sekolah serta ke masyarakat, serta kurangnya perbaikan infrastruktur sekolah, menjadi sejumlah kendala dalam pelaksanaan penerimaan peserta didik baru (PPDB) berdasarkan sistem zonasi.

Kebijakan yang diterapkan pemerintah tersebut menjadi langkah maju untuk tujuan mencerdaskan kehidupan bangsa. Negara, menurut Nisa, memang seharusnya menyiapkan pendidikan yang merata bagi seluruh anak bangsa. Sayangnya, semua itu belum diikuti sarana dan prasarana yang memadai dan akhirnya banyak sekolah yang belum siap untuk melaksanakan sistem zonasi. Wakil Ketua Komisi X DPR yang membawahi urusan pendidikan, Hetifah Sjaifudian, mengatakan, dari data per Juli 2016 terdapat 1.833.323 ruang kelas yang memerlukan perbaikan.

Dia menilai sosialisasi oleh pemerintah terlalu terburu-buru dan menyebabkan banyak daerah yang belum dapat menerapkan kebijakan ini. Pertemuan pertama dilakukan di akhir Februari 2019 dan beberapa bulan kemudian setiap daerah harus dapat membuat kebijakan masingmasing untuk menjabarkan peraturan menteri. "Padahal, mereka harus menyiapkan data-data akurat terbaru seperti distribusi demografi, seberapa banyak anak yang lulus di suatu wilayah atau zonasi, jumlah sekolah, termasuk daya tampung sekolah.

Dari penjelasan tersebut, juga diperkuat oleh pandangan guru. Bahwa faktor penghambat implementasi sistem zonasi dalam penerimaan peserta didik baru adalah jaringan dan sarana prasarana yang kurang memadai. Selain itu, meratanya SDM yang belum mumpuni sehingga sistem zonasi ini belum bisa diterapkan dibeberapa sekolah. Hal tersebut berbanding terbalik dengan tujuan yang ingin dicapai oleh mendikbud.

Dalam sebuah studi yang dilakukan Hanushek (2007) yang menginvestigasi hubungan antara pencapaian pembelajaran dan faktorfaktor input seperti kualitas dan sumber daya sekolah, karakteristik lingkungan keluarga dan pertemanan, dan status sosial-ekonomi menemukan bahwa meskipun terdapat indikasi inefisiensi dalam pendidikan yang mengakibatkan tidak maksimalnya pencapaian pembelajaran, tidak ditemukan kausalitas yang jelas antara input dan 
output dalam pendidikan.

Sebagai contoh, meskipun status sosial-ekonomi peserta didik dapat memberikan kemudahan akses terhadap pendidikan, tanpa adanya kurikulum, kompetensi guru yang baik, dan penyediaan fasilitas pendidikan yang memadai, hasil akhir pendidikan masih belum dapat dikatakan sudah baik.

Kompleksitas permasalahan ketimpangan kualitas pendidikan di Indonesia perlu dilihat dari berbagai sudut pandang. Dengan kebijakan sistem zonasi yang diberlakukan sekarang, upaya pemerataan kualitas pendidikan baru sebatas pada distribusi peserta didik dan dengan upaya peningkatan kompetensi dan fasilitas sekolah yang masih minim.

\section{SIMPULAN}

Berdasarkan temuan peneliti, diterapkannya sistem zonasi dalam penerimaan peserta didik baru menimbulkan pro kontra di kalangan guru. Ada yang setuju diterapkannya sistem zonasi agar predikat sekolah favorit hilang dan agar supaya meratanya pendidikan. Di sisi lain ada yang berpandangan bahwa sistem zonasi belum siap untuk diterapkan karena sumber daya manusia (Guru) belum memadai dan sarana prasarana di sekolah juga belum siap.
Unggulan, Disparitas

Dalam

Pendidikan.Dari

http://mediaindonesia.com/newa/ $\mathrm{read} / 88786 /$ sekolah-unggulandisparitas-dalampendidikan/2017-01-23

Moleong, Lexy. 2006. Metodologi Penelitian KualitatifEdisi Revisi. Bandung: PT Remaja Rosdakarya. Rakhmat, Jalaluddin, 2005. Psikologi Komunikasi. Bandung: PT.Remaja Rosdakarya.

Republik Indonesia. (2017). Permendikbud Nomor 17 Tahun 2017 tentang Penerimaan Peserta Didik Baru pada Taman Kanak Kanak, Sekolah Dasar, Sekolah Menengah Pertama, Sekolah Menengah Atas, Sekolah Menengah Kejuruan atau bentuk Lain yang sederajat.

Thoha, Miftah. (1983). Perilaku

Organisasi. Jakarta: Rajawali Press.

Lickona, Thomas. (1991). Educating for Character. New York: Bantam Books.

Walgito, Bimo. 2004. Pengantar Psikologi Umum. Yogyakarta: Penerbit Andy.

\section{DAFTAR PUSTAKA}

Marthunis, (2017). Sekolah 